\title{
Streptococcus pneumoniae Serotype 6B IgG Antibody Measurement
}

National Cancer Institute

\section{Source}

National Cancer Institute. Streptococcus pneumoniae Serotype 6B Ig G Antibody

Measurement. NCI Thesaurus. Code C142254.

The determination of the amount of Streptococcus pneumoniae serotype 6B Ig G antibody present in a sample. 